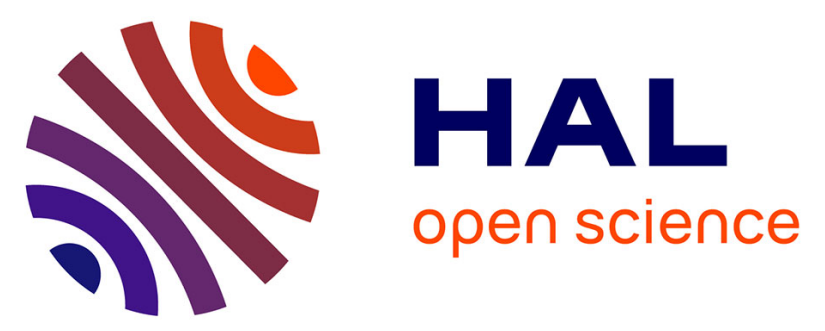

\title{
Atomization of denatured whey proteins as a novel and simple way to improve oral drug delivery system properties
}

Hassana Hsein, Ghislain Garrait, Muhammad Ashraful Mumin, Eric Beyssac, Valerie Hoffart

\section{To cite this version:}

Hassana Hsein, Ghislain Garrait, Muhammad Ashraful Mumin, Eric Beyssac, Valerie Hoffart. Atomization of denatured whey proteins as a novel and simple way to improve oral drug delivery system properties. International Journal of Biological Macromolecules, 2017, 105 (1), pp.801 - 809. 10.1016/j.ijbiomac.2017.07.114 . hal-01658637

\section{HAL Id: hal-01658637 https://hal.science/hal-01658637}

Submitted on 11 Jan 2018

HAL is a multi-disciplinary open access archive for the deposit and dissemination of scientific research documents, whether they are published or not. The documents may come from teaching and research institutions in France or abroad, or from public or private research centers.
L'archive ouverte pluridisciplinaire HAL, est destinée au dépôt et à la diffusion de documents scientifiques de niveau recherche, publiés ou non, émanant des établissements d'enseignement et de recherche français ou étrangers, des laboratoires publics ou privés. 


\section{Accepted Manuscript}

Title: Atomization of denatured whey proteins as a novel and simple way to improve oral drug delivery system properties

Authors: Hassana Hsein, Ghislain Garrait, Muhammad Ashraful Mumin, Eric Beyssac, Valérie Hoffart

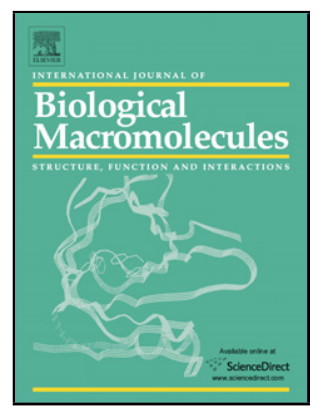

PII: S0141-8130(17)31304-1

DOI: http://dx.doi.org/doi:10.1016/j.ijbiomac.2017.07.114

Reference: BIOMAC 7922

To appear in: $\quad$ International Journal of Biological Macromolecules

Received date: $\quad 11-4-2017$

Revised date: $\quad 14-6-2017$

Accepted date: $\quad$ 17-7-2017

Please cite this article as: Hassana Hsein, Ghislain Garrait, Muhammad Ashraful Mumin, Eric Beyssac, Valérie Hoffart, Atomization of denatured whey proteins as a novel and simple way to improve oral drug delivery system properties, International Journal of Biological Macromoleculeshttp://dx.doi.org/10.1016/j.ijbiomac.2017.07.114

This is a PDF file of an unedited manuscript that has been accepted for publication. As a service to our customers we are providing this early version of the manuscript. The manuscript will undergo copyediting, typesetting, and review of the resulting proof before it is published in its final form. Please note that during the production process errors may be discovered which could affect the content, and all legal disclaimers that apply to the journal pertain. 
Atomization of denatured whey proteins as a novel and simple way to improve oral drug delivery system properties.

Hassana Hsein, Ghislain Garrait, Muhammad Ashraful Mumin, Eric Beyssac *, Valérie Hoffart

Université Clermont-Auvergne, UFR Pharmacie, MEDIS, Clermont-Ferrand F-63001, France

* Corresponding author.

Mailing address: Faculty of Pharmacy - 28 Place Henri Dunant - 63000 Clermont-Ferrand France

Tel.: +33 4731779 62; fax: +33473177959.

E-mail address: eric.beyssac@udamail.fr (E. Beyssac). 


\begin{abstract}
In the sphere of drug delivery, denatured whey protein (DWP) has in recent times gained press. However, to date, no scalable and affordable dosage form has been developed. The objective of our study was to evaluate the potential use of spray-dried DWP as a ready to use excipient for oral drug delivery. Therefore, solid state, FTIR spectra and wettability were studied. Dissolution, mucoadhesion and the effect on paracellular permeability were also evaluated. The spray-dried DWP particles were spherical with $4 \mu \mathrm{m}$ mean diameter. Further, relative to native WP, the spray-dried DWP particles bore reduced wettability, and their structure was characterized by the exposure of a high amount of free thiol and by the formation of intermolecular $\beta$-sheets. The DWP powders were mucoadhesive, enzymatic inhibitors, biocompatible and they induced the opening of tight junctions. Our study shows great potential for the use of spray-drying as a technique to modify the dissolution rate of drugs and enhance the oral bioavailability of molecules. That is, the use of spray drying as a single step ready to use DWP excipient
\end{abstract}

\title{
Abbreviations
}

$\begin{array}{ll}\text { DMEM } & \text { medium Dulbecco's modified eagle medium } \\ \text { DWP } & \text { denatured whey protein } \\ \text { DWP-sp } & \text { spray-dried denatured whey protein particles } \\ \text { EE } & \text { Encapsulation efficiency } \\ \text { NWP } & \text { native whey protein } \\ \text { NWP-sp } & \text { spray-dried native whey protein particles } \\ \text { PEG } & \text { polyethylene glycol } \\ \text { WP } & \text { whey protein }\end{array}$

Keywords

Whey protein, denaturation, spray-drying.

\section{Introduction}

Whey protein (WP) is a valuable milk component, of high nutritional value, that has long been used in the food industry, serving multiple functions including emulsifying, gelling and foaming. In recent times, the nutraceutical and pharmaceutical fields have shown greater interest in WP owing to the encapsulation and protective properties of bioactive molecules therein found.

The potential of WP as a nutraceutical delivery system was initially explored with regard to vitamins such as $A, D, E$, riboflavin [1-4] and minerals such as iron [5]. Probiotics were also successfully encapsulated into WP microparticles, which contributed to increase their survival in the gastro-intestinal tract [6]. Indeed, encapsulation in such matrix system resulted in specific protection from acidic $\mathrm{pH}$, enzymatic degradation, and oxidation to ensure bioactivity [4].

WP then gained interest in the sphere of drug delivery, and controlled release. This was due to WP's ability to selectively release molecules such as ketoprofen [7], theophylline [8] or insulin [9], in response to environmental stimuli such as changes in $\mathrm{pH}$ [10]. 
Up to the conduct of our study, the most commonly studied forms of WP based delivery systems were hydrogels and reticulated microparticles. The use of these two methods is a direct result of the necessity for denaturing WP. The denaturation process itself involves a thermal treatment of a native WP (NWP) aqueous solution. Denaturation induces the unfolding of polymeric chains and thus the exposure of functional groups such as hydrophobic and thiol groups. These groups are in turn responsible for the gelling and reticulating properties of denatured WP (DWP) [11].

Besides interest from a technological point of view, denaturation is necessary to reveal the functional and biopharmaceutical properties of WP. These properties can contribute to the promotion of oral drug bioavailability, more specifically, bioavailability of drugs such as insulin; and this took place after administration of DWP microparticles to rats [9]. Indeed, compared to WP's native form, DWP are highly mucoadhesive [12], and in reticulated microparticle form, exhibited controlled release of encapsulated drugs, opened tight junctions, and inhibited proteolytic enzymatic activity [13].

However, denaturation is not without disadvantages. The main disadvantage is the necessity to use a liquid phase followed by a drying step for storage.

Recently, we have generated unloaded dried DWP particles using spray-drying, a suitable, industrial, scalable and low cost method [14]. Among different drying techniques, spraydrying presents a sound method of choice. This is not only because fluid materials can be converted into solid products via rapid evaporation of solvents, [18] but also because this technique leads, by use of co-spraying, to encapsulation and dry drug-loaded particles in a single-step [15]. This can lead to the formation of particles that are of uniform size, stable and present high encapsulation efficiencies [16]. Even in light of these advantages, very few studies have explored spray-drying of DWP and those which did were not conducted with pharmaceutical applications in mind. For example: Picot and Lacroix increased survival of Bifidobacterium [6]; Koga et al. assessed stabilization of trans-resveratrol [17]; Wang et al. studied stabilization of DHA fish oil [18]; Liu et al. evaluated solubility enhancement of curcuma [19]; and Esfanjani et al. succeeded in encapsulating saffron extracts into DWP/pectin walls [20]. So, many applications for nutraceutical uses but little is known about the biopharmaceutical properties of spray-dried DWP (DWP-sp) and their benefits in oral drug delivery.

For the first time, we propose a new direction for the use of DWP. We propose the spraydrying of DWP for drug encapsulation and oral delivery applications. We do so with the goal of improving oral drug bioavailability.

In testing our hypothesis as to the efficacy of the spray drying methodology, numerous characterizations were performed on the obtained WP-sp powder. These characterizations sought to determine the impact of spray-drying on the DWP structure/morphology and physico-chemical properties such as crystallinity, free thiol content, solubility and wettability. Also studied, with specific regard to oral administration and biopharmaceutical considerations, were apparent dissolution, mucoadhesivity, enzymatic inhibitory effect and the effect on Caco-2 cell permeability. Finally, a model drug, BCS (Biopharmaceutical Classification System) class I, was co-sprayed with DWP to evaluate the impact of encapsulation into DWP, by spray-drying, on the drug release profile. 


\section{Materials and Methods}

\subsection{Materials}

Whey protein isolate $\left(\mathrm{WPI}^{\circledR} 895\right.$, protein $93.5 \%$, fat $0.39 \%$, moisture $4.7 \%$, lactose monohydrate $0.2 \%$ ) was obtained from Fonterra ${ }^{\circledR}$ dairy products, France. Theophylline was purchased from Cooper chemical company, Melun, France. Cell culture products and dissolution buffers components were purchased from Fisher scientific Elancourt, France. All other materials were purchased from Sigma-Aldrich, France.

\subsection{Preparation of spray-dried WP powders}

\subsubsection{WP polymeric solutions}

NWP solutions $(10 \%, \mathrm{w} / \mathrm{w})$ were prepared by re-hydrating whey protein isolate powder (unrefined WP) in deionized water by gentle magnetic stirring for $1 \mathrm{~h}$ at room temperature and then allowed to rest for $2 \mathrm{~h}$ to ensure complete hydration of proteins to form a solution. To prepare DWP solutions, NWP solutions were heated at $80^{\circ} \mathrm{C}$ for $40 \mathrm{~min}$ [21]. The solutions were cooled overnight at room temperature. All WP solutions were adjusted at $\mathrm{pH} 7.0$ with $\mathrm{NaOH} 1 \mathrm{M}$.

Viscosity of all polymeric solutions was measured using a Brookfield DVII+ viscometer at $25^{\circ} \mathrm{C}$, using a SC4-18 spindle at $100 \mathrm{rpm}$ (Brookfield Engineering laboratories, Inc., USA).

\subsubsection{Preparation of particles by spray-drying}

Prepared solutions were spray-dried using a Buchi Mini Spray Dryer (B-290, Buchi ${ }^{\circledR}$ Labortechnik, Flawil, Switzerland), which employs a system of co-current drying via a twofluid nozzle mechanism. The nozzle size was $1.5 \mathrm{~mm}$ and the nozzle cleaning procedure was set at 5 throughout each run. Aspiration was maintained at $100 \%$. Spray drying was performed in the following conditions [14]: inlet temperature $\left(160^{\circ} \mathrm{C}\right)$, pump rate $(5.7$ $\mathrm{mg} \cdot \mathrm{min}^{-1}$ ) and the spray gas flow rate or $\mathrm{Q}$-flow $(50 \mathrm{mmHg}$ or $600 \mathrm{~L} / \mathrm{h}$ ). Outlet temperature was noted for every batch. All powders were then stored in desiccator and yield was calculated as following:

$$
\text { Yield }(\%)=\frac{\text { amount of collected powder }(\mathrm{g})}{\text { amount of initial powder }(\mathrm{g})} \times 100
$$

\subsection{Physico-chemical characterization of unloaded spray-dried WP particles}

\subsubsection{Residual humidity}

Moisture content of spray-dried powders was immediately determined once the powder was collected from the dryer by thermogravimetric method using an infrared balance (Mettler Toledo LJ16 moisture analyser, Viroflay, Switzerland). Two grams of powder were weighed and residual humidity was determined after $10 \mathrm{~min}$ of heating at $80^{\circ} \mathrm{C}$.

\subsubsection{Particle size analysis}

Particle sizes of powders were determined using a laser light diffraction granulometer (Mastersizer S, Malvern Instruments, Malvern, UK) outfitted with an MS64-dry powder feeder sample unit. The lens used was $100 \mathrm{~mm}$, the active beam length was set to $10 \mathrm{~mm}$ and the analysis model used was polydisperse. The results were volume based and the mean volume diameter, $D[3,2]$, was selected to represent the average diameter of particles. 


\subsubsection{Scanning electron microscopy (SEM)}

The external morphology of particles was studied by scanning electron microscopy (JEOL, JSM-6060LV, Tokyo, Japan). The samples were fixed onto double faced carbon tapes and sputtered with thin film of Palladium-Gold for $60 \mathrm{~s}$ using the following device: JEOL JFC-1300. Specimens were examined at $5 \mathrm{KV}$ with different magnifications.

\subsubsection{FTIR analysis}

Structure of WP was analyzed by infrared spectrometer (IRAffinity-1S FTIR, Shimadzu, Kyoto, Japan) equipped with attenuated total reflectance accessory (ATR-FTIR, Miracle 10). Spectra of unrefined WP and spray-dried samples were collected in absorbance mode from 400$4000 \mathrm{~cm}^{-1}$, with 200 scans at $4 \mathrm{~cm}^{-1}$ resolution. Deconvolution of spectra was performed in the amide I region (1600-1700 $\left.\mathrm{cm}^{-1}\right)$ to study secondary structure of WP using the HappGanzel apodization, $20 \mathrm{~cm}^{-1}$ band width and $0.1 \mathrm{~cm}^{-1}$ pathlength using IR-Solution software.

\subsubsection{Free thiol content determination}

The amount of free thiol in WP samples was determined spectrophotometrically with Ellman's reagent (Pierce Biotechnology, Rockford, USA) according to the manual instructions guide [12,22]. First, NWP-sp and DWP-sp powders were dissolved in deionized water (pH 6.8) at $20 \mathrm{mg} \cdot \mathrm{mL}^{-1}$ and $250 \mu \mathrm{L}$ of the obtained WP solutions were mixed with $2500 \mu \mathrm{L}$ of reaction buffer and $50 \mu \mathrm{L}$ of Ellman's reagent. The samples were incubated for $15 \mathrm{~min}$ at room temperature followed by measurement of absorbance at $412 \mathrm{~nm}$. The number of thiol groups was calculated using a molar extinction coefficient for 5-thio 2-nitrobenzoic acid (TNB) of $14150 \mathrm{M}^{-1} \cdot \mathrm{cm}^{-1}$ at $412 \mathrm{~nm}$ (Ellman's reagent manual instructions guide, Pierce Biotechnology).

\subsubsection{Contact angle measurements}

Contact angle measurements were done to analyze the wettability of WP powders $[23,24]$ using Theta Lite goniometer (Attension, Stockholm, Sweden) equipped with IC capture software. Samples (200 mg of spray-dried powders) were compacted (1.5 $\mathrm{t}$ of pressure during $30 \mathrm{~s}$ ) prior to experiments in order to get a smooth surface allowing accurate measurements. Then, samples were placed on a 3D manipulator plate which was adjusted to be straight and horizontal and a micro-syringe containing deionized water was mounted above the samples. Data was acquired as one droplet $(10 \mu \mathrm{L})$ was deposited from the microsyringe on the sample. Resulting images were analyzed by ImageJ program to calculate contact angle. Each sample was prepared in triplicate and two independent measurements were made for each surface.

\subsubsection{Solubility study}

Solubility study was performed according to the excess substrate addition method (Florence and Attwood, 2006; Martin and Sinko, 2011). NWP-sp or DWP-sp were added in excess to 20 $\mathrm{mL}$ deionized water or $\mathrm{pH} 1.2,4.5,6.8$ or 7.8 european pharmacopeia buffers under agitation. After 24 h, suspensions were centrifuged $10000 \mathrm{rpm}, 10 \mathrm{~min}$ and supernatants were analyzed according to BCA method (Bio Basic Inc, Markham Ontario, Canada) to determine WP solubility. 


\subsection{Biopharmaceutical characterization of unloaded spray-dried WP particles for oral administration}

\subsubsection{Apparent dissolution of WP powders}

Dissolution profiles of NWP-sp and DWP-sp powders (300 mg) were investigated using an automated flow-through cell dissolution apparatus (USP 4, Sotax, Aesch, Switzerland) with $200 \mathrm{~mL}$ of $\mathrm{pH} 1.2$ or $6.8 \mathrm{USP}$ buffer at $37^{\circ} \mathrm{C}$ in a closed loop setting ( $22.6 \mathrm{~mm}$ cells). Rate was fixed at $20 \mathrm{~mL}$. $\mathrm{min}^{-1}$ and a whatman GF/F filters were used in each cell. Samples $(1 \mathrm{~mL}$ replaced by fresh buffer) were withdrawn at set interval times up to $8 \mathrm{~h}$ and centrifuged at $5000 \mathrm{rpm}$ during $5 \mathrm{~min}$. Quantities of released WP were calculated using a UV spectrophotometer (Jenway 7315, Staffordshire, United Kingdom) at $280 \mathrm{~nm}$.

\subsubsection{Mucoadhesive properties}

Mucoadhesion of WP powders was evaluated using the technique of non-everted gut sacs [25] in accordance with The Code of Ethics of the EU Directive 2010/63/EU for animal experiments. After anesthesia, rat jejunum was cut into equal fragments of $10 \mathrm{~cm}$ and washed several times with saline before filling it with $2 \mathrm{~mL}$ of suspension containing either $500 \mathrm{mg}$ of NWP-sp or DWP-sp powders in Krebs Henseleit buffer (D-glucose 2 g.L L $^{-1}$, magnesium sulfate $0.141 \mathrm{~g} . \mathrm{L}^{-1}$, potassium phosphate monobasic $0.16 \mathrm{~g} . \mathrm{L}^{-1}$, potassium chloride $0.35 \mathrm{~g} . \mathrm{L}^{-1}$, sodium chloride $6.9 \mathrm{~g} . \mathrm{L}^{-1}$, calcium chloride dihydrate $0.373 \mathrm{~g} . \mathrm{L}^{-1}$ and sodium bicarbonate $\left.2.1 \mathrm{~g} . \mathrm{L}^{-1}\right)$. Then, gut sacs were sutured and placed in tissue chambers containing $15 \mathrm{~mL}$ of warmed $\left(37^{\circ} \mathrm{C}\right)$, oxygenated $\left(95 \% \mathrm{O}_{2} / 5 \% \mathrm{CO}_{2}\right)$ Krebs Henseleit modified buffer for $1 \mathrm{~h}$. After this stipulated time, sacs were opened, content collected and then dried in an incubator at $60^{\circ} \mathrm{C}$ until constant weight to determine the remaining quantity of WP. The rate of adhered powder onto the sac was determined by subtracting the residual mass from the initial mass via Equation (2).

Powder mucoadhesion $(\%)=\frac{\text { Residual mass }}{\text { Initial mass }} \times 100$

\subsubsection{Enzymatic inhibition properties}

Effects of WP-sp powders on enzymatic activity was studied with trypsin and $\alpha$-chymotrypsin according to Ameye et al procedure [26].

\section{$\alpha$-chymotrypsin inhibition activity}

NWP-sp or DWP-sp were dispersed in Tris HCL pH 7.8 buffer at $1 \%$ final concentration $(\mathrm{w} / \mathrm{w})$. The substrate $\mathrm{N}$-benzoyl-L-tyrosine $\mathrm{p}$-nitroanilide (BATPNA) was dissolved at $1.18 \mathrm{mM}$ in dimethylformamide (DMF) while $\alpha$-chymotrypsin from bovine pancreas was dissolved in 10 $\mathrm{mM} \mathrm{HCl}$. Then $1 \mathrm{~mL}$ of WP solutions, $1 \mathrm{~mL}$ of BATPNA and $40 \mathrm{UI}$ of $\alpha$-chymotrypsin were mixed at $37^{\circ} \mathrm{C}$ for 30 min before stopping the reaction by the addition of $1 \%$ trichloroacetic acid. Finally, the metabolite $p$-nitroaniline formed was measured spectrophotometrically at $405 \mathrm{~nm}$.

Control experiments were conducted using exactly the same protocol but without addition of WP. The activity of $\alpha$-chymotrypsin in control was taken as $100 \%$ and the activity of partially $\alpha$-chymotrypsin incubated in the presence of WP was expressed relative to $100 \%$ activity calculated comparing the absorption of reaction mixtures.

\section{Trypsin inhibition activity}

Same WP-sp powders were dispersed in $\mathrm{pH} 7.4$ phosphate buffer at $1 \%$ final concentration $(w / w)$. The substrate $\mathrm{N}$-benzoyl dl-arginine $\mathrm{p}$-nitroanilide (BAPNA) was dissolved at $20 \mathrm{mM}$ in 
dimethylformamide (DMF) while trypsin was dissolved in $10 \mathrm{mM} \mathrm{HCl}$. Then $1 \mathrm{~mL}$ of WP solutions, $1 \mathrm{~mL}$ of BAPNA and $30 \mathrm{UI}$ of trypsin were mixed at $37^{\circ} \mathrm{C}$ for $30 \mathrm{~min}$ before stopping the reaction by the addition of $1 \%$ trichloroacetic acid. Finally, the percentage of inhibition was calculated in an exactly similar manner as applied in the case of $\alpha$-chymotrypsin inhibition assay.

\subsubsection{Cytotoxicity and permeability studies of PEG 4000 on Caco-2 cells}

The Caco-2 cells were obtained from the American Type Culture Collection (ATCC, Rockville, $\mathrm{MD})$. Polycarbonate transwell permeable supports $(0.4 \mu \mathrm{m}$ pore size) were seeded with $5.10^{5}$ cell per well at passage 35 and incubated for 21 days with DMEM medium (Dulbecco's modified eagle medium supplemented with $15 \%$ fetal bovine serum, $1 \%$

penicillin/streptomycin and $1 \%$ L-glutamine. Cytotoxicity studies were then performed to evaluate the viability of cells in the presence of NWP-sp and DWP-sp powders at $0.5 \%(\mathrm{~W} / \mathrm{v})$. The viability of the cells was evaluated by trypan blue exclusion (final concentration of $0.2 \%$ in PBS) [27].

Transport studies were also done after complete cells differentiation and only wells exhibiting transepithelial electrical resistance (TEER, electrode STX2, EVOMX World Precision Instruments, Sarasota, FL, USA) greater than $600 \Omega . \mathrm{cm}^{2}$ were used. Before experiment, medium was withdrawn and cells monolayers were washed twice with $1 \mathrm{~mL}$ PBS buffer. Then $500 \mu \mathrm{L}$ of the following samples were added to the apical side of cells monolayers: WPsp powders dispersed at $0.5 \%\left(\mathrm{w} / \mathrm{v}\right.$ ) in HBSS buffer containing $1 \mathrm{mg} \cdot \mathrm{mL}^{-1}$ PEG 4000 as a model molecule $[28,29]$ while basolateral side contained only HBSS buffer. Reference corresponded to untreated cells. Cells were incubated at $37^{\circ} \mathrm{C}$ during $120 \mathrm{~min}$. At predetermined times, TEER was measured and $500 \mu \mathrm{L}$ were taken out from basolateral side and replaced by fresh HBSS. Passage of PEG 4000 was determined on withdrawn samples by colorimetric method as described by Nag et al. 1996 [30]. TEER was recorded throughout incubation and during $24 \mathrm{~h}$ for recovery period as a measure of cell viability and monolayer integrity. At the end of the experiment, permeability studies were stopped by removing the apical medium and washing the cells three times with PBS. Immediately fresh medium incubated at $37^{\circ} \mathrm{C}$ was replaced. The monolayers were allowed to regenerate for $24 \mathrm{~h}$ at $37^{\circ} \mathrm{C}$ in an atmosphere of $95 \%$ air and $5 \% \mathrm{CO} 2$ at $90 \%$ relative humidity.

Results are expressed as apparent permeability coefficient (Papp) and variation of TEER (\%) compared to initial values, calculated according to Equation (3) and (4).

$\operatorname{TEER}(\%)=\frac{\operatorname{TEER}(\mathrm{t})}{\operatorname{TEER}(\mathrm{t} 0)} \times 100$

$\mathrm{P}$ app $\left(\mathrm{cm} \cdot \mathrm{s}^{-1}\right)=\left(\frac{\mathrm{dQ}}{\mathrm{dt}}\right) \times \frac{1}{\mathrm{~A} \cdot \mathrm{C} 0}$

where $\mathrm{dQ} / \mathrm{dt}$ is the flux of tested product across the monolayer $\left(\mathrm{mol}^{-1} \mathrm{~s}^{-1}\right), \mathrm{C}_{0}$ is the initial concentration in the apical compartment $\left(\mathrm{mol}^{\mathrm{mL}} \mathrm{L}^{-1}\right)$, and $\mathrm{A}$ is the surface area of the monolayer $\left(1.12 \mathrm{~cm}^{2}\right)$. The Papp values are expressed as $\mathrm{cm} \cdot \mathrm{s}^{-1}$. The Papp values were calculated for the 120 min period of the experiment.

\subsection{Statistical analysis}

All experiments, except SEM, were done in triplicate. Values are presented as mean \pm standard deviation (SD) and statistical comparisons were performed using analysis of 
variance (ANOVA). $p<0.05$ was used as the level of significance $(p<0.01$ was considered to be very significant).

\section{Results and discussion}

\subsection{Production of DWP particle powder}

Spray-drying was used to produce DWP particles intended to be a biopolymer wall and matrix material for drug delivery. Four variables (yield, residual humidity, particle size and outlet temperature) were consequently measured (Table 1 ).

Yield was about $80 \%$, satisfying for the laboratory scale. Residual humidity was under $5 \%$, in accordance with values recommended in the pharmacopeia for solid dosage forms to ensure good storage of product without mold development and bacterial growth [31].

Moreover, particle shape and size were monitored, since these can influence drug release kinetics. Laser diffraction showed that mean particles size $D[3,2]$ was around $4 \mu \mathrm{m}$. This result was confirmed by SEM where spherical particles were identified with two populations: under 3 and around $6 \mu \mathrm{m}$ (Fig. 1). These distributions are characteristic of WP-sp powders and are similar to those reported in literature $[17,20]$. Evidence of indentation and wrinkles on powder surface (Fig. 1) might be due to the rapid evaporation and cooling process during drying [32] and to the protein nature of the polymeric matrix $[20,33]$. The same observations were made by Khem et al [34]and Shen and Quek [35].

Concerning outlet temperature, recorded values $\left(72 \pm 1^{\circ} \mathrm{C}\right)$ are acceptable since heating time is very short. Studies showed that even thermolabile proteins such as insulin remained stable and bioactive at these temperatures [36].

Nevertheless, outlet temperature was higher with NWP and thus the yield (approx. 87\%) (Table 1) in link to lower viscosity of NWP compared to DWP solutions (2 vs. $47 \mathrm{cP}$ ). In fact, the nozzle plays the role of a heat exchanger between gas flow and feed solution, thereby when viscosity increased, energy supplied to the nozzle should overcome larger viscous forces resulting in decreased outlet temperature and yield [37]. Viscosity appeared clearly as a key parameter to optimize, if necessary, product stability and yield.

It is noteworthy to mention that, despite the theory of aggregate formation following denaturation [38], in both cases, particle size distributions were similar.

\subsection{Physico-chemical properties of spray-dried DWP particles}

\subsubsection{FTIR}

FTIR spectra were performed in order to get molecular information about the conformational behavior of WP following denaturation and atomization.

As shown in Fig. 2a, spectra of NWP presented five major absorption peaks in the range of (i) $1200-1350 \mathrm{~cm}^{-1}$, related to combination of $\mathrm{N}-\mathrm{H}$ in-plane bending with $\mathrm{C}-\mathrm{N}$ stretching vibrations (amide III); (ii) $1400-1550 \mathrm{~cm}^{-1}$, associated to $\mathrm{N}-\mathrm{H}$ bending (amide II); (iii) 1600$1700 \mathrm{~cm}^{-1}$, governed by stretching vibration of $\mathrm{C}=\mathrm{O}$ and $\mathrm{C}-\mathrm{N}$ groups (amide I); (iv) 2850-2980 $\mathrm{cm}^{-1}$, assigned to symmetric and asymmetric C-H stretching vibrations; and (v) 3000-3600 $\mathrm{cm}^{-1}$, attributed to free and bound $\mathrm{O}-\mathrm{H}$ and $\mathrm{N}-\mathrm{H}$ groups [39]. Deconvolution spectra were recorded in the amide I region $\left(1600-1700 \mathrm{~cm}^{-1}\right)$ since this region is sensitive and indicative 
of the protein secondary structure (Fig. 2b) $[1,40]$. The amide I band of unrefined WP contained five individual components; their assignments are well-described in the literature. The strongest peak at $1631 \mathrm{~cm}^{-1}$ is characteristic of amide groups involved in the extended $\beta$ sheet structure [41]. Bands at 1647 and $1666 \mathrm{~cm}^{-1}$ are representative of $\alpha$-helix/unordered structures and turns respectively. Component at $1678 \mathrm{~cm}^{-1}$ is attributed to $\beta$-sheet while that at $1689 \mathrm{~cm}^{-1}$ correspond to intermolecular anti-parallel $\beta$-sheet. WP-sp in the chosen operating conditions conserved the secondary structure as seen in Fig. $2 b[40,42,43]$. However, denaturation induced a dramatic alteration in the amide I band characterized by a featureless broadband between 1630 and $1680 \mathrm{~cm}^{-1}$ indicating the loss of native structures and more precisely the unfolding of polypeptide segments [44]. Though, the $\alpha-$ helix/unordered $\left(1647 \mathrm{~cm}^{-1}\right)$ and turns $\left(1666 \mathrm{~cm}^{-1}\right)$ structures were barely conserved. In addition, the strongest band assigned at $1632 \mathrm{~cm}^{-1}$ shifted to $1628 \mathrm{~cm}^{-1}$ which corresponds to the appearance of intermolecular $\beta$-sheets resulting from aggregation instead of intramolecular $\beta$-sheets [43]. This shift occurred simultaneously with an increase in the 1685 $\mathrm{cm}^{-1}$ component showing that additional intermolecular antiparallel $\beta$-sheets are formed. Thus, the main secondary conformation of DWP-sp was antiparallel $\beta$-sheets characterized by unfolding and aggregation of proteins. This structure was similar to FTIR results obtained in our previous study on DWP powder obtained by polymeric solution freeze-drying [12] indicating that heat elements during spray-drying had no influence on DWP-sp structure.

\subsubsection{Free thiol determination}

The number of free thiol was determined in order to evaluate the impact of denaturation and spray-drying on the exposition of these functional groups (Fig. 3). As expected, denaturation favored exposition of free thiol in both, solution and spray-dried powder forms. Unfolding of polymeric chains following denaturation was the main reason for the exponential increase in thiol groups [12] whereas rearrangement of functional groups during particle formation probably decreased accessible thiol groups following spray-drying. Rearrangement could be the reformation of aggregates by thiol-disulfide interchange [45] or the sharing of total free thiol groups between the surface and the core of particles.

Despite the mentioned decrease, the amount of accessible free thiol remained very high after denaturation compared to the amount of thiol sufficiently effective to exhibit functional properties such as mucoadhesion and bioavailability enhancement as described for other thiomers $[46,47]$.

\subsubsection{Wettability}

Contact angle between a liquid droplet and a flat surface is a direct indicator of the surface wettability. Value less than $90^{\circ}$ characterize good wettability properties. The two explored polymers showed moderate to good wettability $\left(<90^{\circ}\right)$ with two different behaviors. For NWP-sp, contact angle was around $50 \pm 2^{\circ}$, which is in agreement with published data [48]. Denaturation significantly increased contact angle to reach $82 \pm 2^{\circ}$. Though, denaturation decreased WP wettability, which could be correlated to the exposure of hydrophobic groups following chain unfolding induced by denaturation.

\subsubsection{Solubility}


Whey protein structure are known to be thermosensitive and prone to solubility changes following denaturation [49] but no information is available about these properties following atomization.

Unrefined WP were highly soluble with $\mathrm{pH}$ dependency, solubility increasing with pH (Table 2 ), in agreement with solubility values determined by Pelegrine and Gasparetto [49]. Spraydrying of NWP did not significantly affect solubility indicating the absence of protein degradation through denaturation during atomization in the selected operating conditions [50].

On the contrary, denaturation induced a sharp decrease in DWP-sp solubility irrespective of the $\mathrm{pH}$ (Table 2). Insolubility of DWP-sp is due to conformational changes of proteins resulting from unfolding and exposure of hydrophobic and thiol groups leading to hydrophobic and disulfide intermolecular bonds [11,38]. These interactions are responsible for intermolecular aggregation as shown in FTIR spectra resulting in a cross-linked insoluble network [51]. Insolubility of DWP-sp was a required factor for further applications such as controlled release of encapsulated drugs and can represent a promising advantage as a carrier to avoid fast release.

\subsection{Biopharmaceutical properties of spray-dried DWP powders}

Strategies developed to improve drug bioavailability are mainly based on excipient biopharmaceutical properties. These strategies include: (i) prolonging gastro-intestinal residence time by choosing mucoadhesive excipient, (ii) protecting API from enzymatic degradation by using enzymatic inhibitory and (iii) promoting paracellular transport by using absorption enhancers [52]. In addition to these strategies, controlled release is of great importance since it allows improving drug efficacy, reducing toxicity, and improving patient compliance and convenience [53].

\subsubsection{Apparent dissolution}

Apparent dissolution profiles of NWP-sp and DWP-sp powders were evaluated in a USP 4 closed system, at pH 1.2 and at pH 6.8, by monitoring the release of WP (Fig. 4).

NWP-sp exhibited very fast dissolution with $70 \%$ released in 5 min whatever the $\mathrm{pH}$. At pH 6.8 , dissolution was complete but at $\mathrm{pH} 1.2$, dissolution didn't exceed $75 \%$. Incomplete dissolution despite working in sink conditions was probably due to the moderate wettability properties [54,55] of NWP-sp and to the hydrodynamic conditions. In flow-through cell dissolution, flow is laminar and shear is provided by the pulsatile flow over the particles [56]. Gentle laminar flow may cause the deposit of a thin layer of particles on the glass beads, so that, in the case of NWP-sp, aggregation may occur and thus reduce the extent of dissolution.

Denaturation modified completely the WP dissolution profile: DWP-sp dissolution was zero at $\mathrm{pH}$ 1.2. We have to note that it was impossible to work in sink conditions because its solubility was far too low (approx. $2 \mu \mathrm{g} . \mathrm{mL}^{-1}$ ) regarding experimental conditions. At $\mathrm{pH} 6.8$, DWP-sp exhibited a zero-like order dissolution rate.

This low release rate correlates with the solubility study and is promising for drug controlled delivery.

\subsubsection{Mucoadhesive properties}


Mucoadhesive behaviors of spray-dried powders were assessed by measuring adhesion of particles to isolated rat intestinal fragments after $1 \mathrm{~h}$ : mucoadhesivity of NWP-sp was low $(19.3 \pm 2.9 \%)$ whereas DWP-sp exhibited high mucoadhesion to the intestine $(48.7 \pm 4.5$ and $40.9 \pm 3.4 \%$, respectively).

Though, denaturation favored mucoadhesive properties of WP-sp powders. This was due to unfolding of polymeric chains following denaturation, which expose functional groups such as free thiols and hydrophobic groups. Thiol functional groups are the main key for mucoadhesion because they allow establishment of covalent disulfide bonds between polymer and cysteines of the mucus [12]. By comparison with mucoadhesivity of hydrogel or microparticles made of DWP $[12,57]$, these results effectively proved that the denaturation clearly exhibited these properties and the spray-drying technique turned to maintain them.

Mucoadhesivity of DWP-sp, especially compared to NWP-sp, render them to be good carriers for drug administration because mucoadhesion prolong residence time and facilitate intimate contact with the intestinal mucosa playing though an important role in enhancing bioavailability [58].

\subsubsection{Enzymatic inhibitory effect}

The protective property of a polymeric delivery system towards enzymatic degradation is primordial in case of oral administration of enzyme-sensitive drug like therapeutic proteins. Amongst luminally secreted proteases and membrane bound proteases, trypsin and $\alpha$ chymotrypsin are the most abundant secreted proteases with the highest enzymatic activity and they were though chosen as model proteases to study the inhibition effect of WP [59]. Both NWP-sp and DWP-sp powders inhibited enzymatic activity (Fig. 5). Nevertheless, the efficacy of DWP-sp to inhibit the enzymatic action was significantly superior to NWP-sp (Fig. 5). Being a protein moiety, WP can be considered as a substrate for proteases and thus can play the role of inhibitor as observed with the commonly used Bowman-Birk inhibitor extracted from soybean protein [60].

\subsubsection{Cytotoxicity studies and paracellular transport enhancement}

Cytotoxicity study was carried on by the blue trypan exclusion test which indicates membrane integrity [61]. None of the tested polymers induced cell cytotoxicity: more than $90 \%$ viable cells were counted after $2 \mathrm{~h}$ incubation $(96.54 \pm 2.33 \%, 93.07 \pm 3.65 \%$ and 91.52 $\pm 4.18 \%$ for NWP-sp and DWP-sp, respectively).

So, DWP-sp, by comparison to other calcium chelating agent used as enzymatic inhibitor (EDTA, EGTA $[59,62])$, doesn't present any toxic effect and though can be considered more advantageous for drug delivery.

The effect of spray-dried powders on the paracellular transport of PEG 4000 was assessed. The transport of this model compound is known to be through tight junction opening due to its hydrophilic and high molecular weight characters [29].

At the beginning of experiments, all Caco- 2 monolayer cells presented TEER values greater than $600 \Omega . \mathrm{cm}^{2}$ indicating the integrity of the tight junctional complex. In comparison to untreated cells and to cells treated with NWP-sp, addition of DWP-sp powders to the apical side induced a significantly decrease in TEER values and an increase in the Papp of PEG 4000. TEER decreased to reach $60 \%$ of its initial value after $2 \mathrm{~h}$ incubation (Fig. 6). At the tight 
junctional complex, TEER values are usually reduced due to water and ion passage through the paracellular route [63]. Thus, DWP-sp powders seemed to exert an effect on paracellular permeability by opening tight junctions. This hypothesis was confirmed by the two time increased Papp of PEG 4000 (Table 3). Similar results were obtained by Déat-Lainé et al. [27], evaluating the effect of DWP polymeric solutions and microparticles on paracellular passage of insulin on Caco- 2 cells.

Thus, spray-drying preserved well DWP properties to enhance paracellular transport and could be thus, an interesting alternative to produce dried DWP particles in a single-step.

The ability of Caco-2 monolayers to recover to their original impermeable state after sample removal was evaluated by monitoring TEER values for up to $24 \mathrm{~h}$. For all samples, TEER values returned to their baseline levels in $24 \mathrm{~h}$. Consequently, as previously demonstrated for DWP microparticles [27], DWP-sp powder can be considered as a good excipient to temporary modulate paracellular permeability and to promote drug absorption without toxic effect.

\section{Conclusion}

High yield and low residual humidity unloaded DWP-sp particles, with almost perfect spherical forms, were obtained in our study using spray-drying method. DWP-sp powder exhibited the characteristics required to increase bioavailability of a drug after oral administration.

Compared with native one, DWP-sp showed an unfolding of polypeptide segments with intermolecular $\beta$-sheets resulting from aggregation. The free thiol exposure favored by denaturation was preserved after drying, and thus the DWP-sp powder was mucoadhesive at intestinal $\mathrm{pH}$ due to possible establishment of covalent disulfide bridges between mucin and polymer.

The obtained powder of DWP-sp, known to be calcium chelating agent, exhibited a protective inhibitory activity effect against proteases; which is a requirement for therapeutic peptide/protein oral administration. Moreover, this powder had no cytotoxic effect on Caco2 cells and promoted reversible opening of tight junction, which allow increasing drug absorption by paracellular route.

In addition, dissolution of DWP-sp showed interesting slow release properties to push forward investigations concerning impact on drug controlled release for oral delivery.

In view of the observed physico-chemical and biopharmaceutical properties, manifested in our study, spray drying is a single step technique for preparing DWP based particles to operate as excipients for modifying the dissolution rate of drugs and enhancing the bioavailability of molecules, such as therapeutic proteins. 


\section{References}

[1] L. Beaulieu, L. Savoie, P. Paquin, M. Subirade, Elaboration and characterization of whey protein beads by an emulsification/cold gelation process: application for the protection of retinol, Biomacromolecules. 3 (2002) 239-248.

[2] F. Diarrassouba, G. Remondetto, L. Liang, G. Garrait, E. Beyssac, M. Subirade, Effects of gastrointestinal $\mathrm{pH}$ conditions on the stability of the $\beta$-lactoglobulin/vitamin D3 complex and on the solubility of vitamin D3, Food Res. Int. 52 (2013) 515-521. doi:10.1016/j.foodres.2013.02.026.

[3] W. Somchue, W. Sermsri, J. Shiowatana, A. Siripinyanond, Encapsulation of $\alpha$-tocopherol in protein-based delivery particles, Food Res. Int. 42 (2009) 909-914. doi:10.1016/j.foodres.2009.04.021.

[4] L. Chen, G.E. Remondetto, M. Subirade, Food protein-based materials as nutraceutical delivery systems, Trends Food Sci. Technol. 17 (2006) 272-283. doi:10.1016/j.tifs.2005.12.011.

[5] G.E. Remondetto, E. Beyssac, M. Subirade, Iron availability from whey protein hydrogels: an in vitro study, J. Agric. Food Chem. 52 (2004) 8137-8143. doi:10.1021/jf040286h.

[6] A. Picot, C. Lacroix, Encapsulation of bifidobacteria in whey protein-based microcapsules and survival in simulated gastrointestinal conditions and in yoghurt, Int. Dairy J. 14 (2004) 505-515. doi:10.1016/j.idairyj.2003.10.008.

[7] M. Betz, C.A. García-González, R.P. Subrahmanyam, I. Smirnova, U. Kulozik, Preparation of novel whey protein-based aerogels as drug carriers for life science applications, J. Supercrit. Fluids. 72 (2012) 111-119. doi:10.1016/j.supflu.2012.08.019.

[8] G. Hébrard, V. Hoffart, J.-M. Cardot, M. Subirade, M. Alric, E. Beyssac, Investigation of coated whey protein/alginate beads as sustained release dosage form in simulated gastrointestinal environment, Drug Dev. Ind. Pharm. 35 (2009) 1103-1112. doi:10.1080/03639040902783066.

[9] E. Déat-Lainé, V. Hoffart, G. Garrait, J.-F. Jarrige, J.-M. Cardot, M. Subirade, E. Beyssac, Efficacy of mucoadhesive hydrogel microparticles of whey protein and alginate for oral insulin delivery, Pharm. Res. 30 (2013) 721-734. doi:10.1007/s11095-012-0913-3.

[10] N. Kashyap, N. Kumar, M.N.V.R. Kumar, Hydrogels for pharmaceutical and biomedical applications, Crit. Rev. Ther. Drug Carrier Syst. 22 (2005) 107-149.

[11] J.B.G. Frank J. Monahan, Effect of $\mathrm{pH}$ and temperature on protein unfolding and thiol/disulfide interchange reactions during heat-induced gelation of whey proteins, J. Agric. Food Chem. - J AGR FOOD CHEM. 43 (2002). doi:10.1021/jf00049a010.

[12] H. Hsein, G. Garrait, E. Beyssac, V. Hoffart, Whey protein mucoadhesive properties for oral drug delivery: Mucin-whey protein interaction and mucoadhesive bond strength, Colloids Surf. B Biointerfaces. 136 (2015) 799-808. doi:10.1016/j.colsurfb.2015.10.016.

[13] E. Déat-Lainé, V. Hoffart, J.-M. Cardot, M. Subirade, E. Beyssac, Development and in vitro characterization of insulin loaded whey protein and alginate microparticles, Int. J. Pharm. 439 (2012) 136-144. doi:10.1016/j.ijpharm.2012.10.003.

[14] H. Hsein, G. Garrait, F. Tamani, E. Beyssac, V. Hoffart, Denatured Whey Protein Powder as a New Matrix Excipient: Design and Evaluation of Mucoadhesive Tablets for Sustained Drug Release Applications, Pharm. Res. 34 (2017) 365-377. doi:10.1007/s11095-016-2067-1.

[15] O.R. Roustapour, M. Hosseinalipour, B. Ghobadian, F. Mohaghegh, N.M. Azad, A proposed numerical-experimental method for drying kinetics in a spray dryer, J. Food Eng. 90 (2009) 2026. doi:10.1016/j.jfoodeng.2008.05.031.

[16] M. Dixit, A.G. Kini, P.K. Kulkarni, Preparation and characterization of microparticles of piroxicam by spray drying and spray chilling methods, Res. Pharm. Sci. 5 (2010) 89-97. 
[17] C.C. Koga, J.E. Andrade, M.G. Ferruzzi, Y. Lee, Stability of Trans-Resveratrol Encapsulated in a Protein Matrix Produced Using Spray Drying to UV Light Stress and Simulated Gastro-Intestinal Digestion, J. Food Sci. 81 (2016) C292-C300. doi:10.1111/1750-3841.13176.

[18] Y. Wang, W. Liu, X.D. Chen, C. Selomulya, Micro-encapsulation and stabilization of DHA containing fish oil in protein-based emulsion through mono-disperse droplet spray dryer, J. Food Eng. 175 (2016) 74-84. doi:10.1016/j.jfoodeng.2015.12.007.

[19] W. Liu, X.D. Chen, Z. Cheng, C. Selomulya, On enhancing the solubility of curcumin by microencapsulation in whey protein isolate via spray drying, J. Food Eng. 169 (2016) 189-195. doi:10.1016/j.jfoodeng.2015.08.034.

[20] A.F. Esfanjani, S.M. Jafari, E. Assadpoor, A. Mohammadi, Nano-encapsulation of saffron extract through double-layered multiple emulsions of pectin and whey protein concentrate, J. Food Eng. 165 (2015) 149-155. doi:10.1016/j.jfoodeng.2015.06.022.

[21] T. Lefèvre, M. Subirade, Molecular differences in the formation and structure of fine-stranded and particulate $\beta$-lactoglobulin gels, Biopolymers. 54 (2000) 578-586. doi:10.1002/10970282(200012)54:7<578::AID-BIP100>3.0.CO;2-2.

[22] D. Guggi, A.H. Krauland, A. Bernkop-Schnürch, Systemic peptide delivery via the stomach: in vivo evaluation of an oral dosage form for salmon calcitonin, J. Control. Release Off. J. Control. Release Soc. 92 (2003) 125-135.

[23] K. Grundke, K. Pöschel, A. Synytska, R. Frenzel, A. Drechsler, M. Nitschke, A.L. Cordeiro, P. Uhlmann, P.B. Welzel, Experimental studies of contact angle hysteresis phenomena on polymer surfaces - Toward the understanding and control of wettability for different applications, Adv. Colloid Interface Sci. 222 (2015) 350-376. doi:10.1016/j.cis.2014.10.012.

[24] K.L. Mittal, Contact Angle, Wettability and Adhesion, BRILL, 2008.

[25] H. Takeuchi, J. Thongborisute, Y. Matsui, H. Sugihara, H. Yamamoto, Y. Kawashima, Novel mucoadhesion tests for polymers and polymer-coated particles to design optimal mucoadhesive drug delivery systems, Adv. Drug Deliv. Rev. 57 (2005) 1583-1594. doi:10.1016/j.addr.2005.07.008.

[26] D. Ameye, J. Voorspoels, J.P. Remon, J. Demeester, S.C. De Smedt, Optimisation of an in vitro procedure for the determination of the enzymatic inhibition potency of multifunctional polymers, J. Controlled Release. 68 (2000) 413-417. doi:10.1016/S0168-3659(00)00274-1.

[27] E. Déat-Lainé, V. Hoffart, G. Garrait, E. Beyssac, Whey protein and alginate hydrogel microparticles for insulin intestinal absorption: evaluation of permeability enhancement properties on Caco-2 cells, Int. J. Pharm. 453 (2013) 336-342. doi:10.1016/j.ijpharm.2013.06.016.

[28] J. Linnankoski, J. Mäkelä, J. Palmgren, T. Mauriala, C. Vedin, A.-L. Ungell, L. Lazorova, P. Artursson, A. Urtti, M. Yliperttula, Paracellular porosity and pore size of the human intestinal epithelium in tissue and cell culture models, J. Pharm. Sci. 99 (2010) 2166-2175. doi:10.1002/jps.21961.

[29] P.J. Shah, V.V. Jogani, P. Mishra, A.K. Mishra, T. Bagchi, A.R. Misra, Role of 99mTc-mannitol and $99 \mathrm{mTc}-\mathrm{PEG}$ in the assessment of paracellular integrity of cell monolayers, Nucl. Med. Commun. 28 (2007) 653-659. doi:10.1097/MNM.0b013e32822a0e8b.

[30] A. Nag, G. Mitra, P.C. Ghosh, A colorimetric assay for estimation of polyethylene glycol and polyethylene glycolated protein using ammonium ferrothiocyanate, Anal. Biochem. 237 (1996) 224-231. doi:10.1006/abio.1996.0233.

[31] Y.-F. Maa, P.-A. Nguyen, J.D. Andya, N. Dasovich, T.D. Sweeney, S.J. Shire, C.C. Hsu, Effect of Spray Drying and Subsequent Processing Conditions on Residual Moisture Content and Physical/Biochemical Stability of Protein Inhalation Powders, Pharm. Res. 15 (1998) 768-775. doi:10.1023/A:1011983322594.

[32] M. Rosenberg, I.J. Kopelman, Y. Talmon, A Scanning Electron Microscopy Study of Microencapsulation, J. Food Sci. 50 (1985) 139-144. doi:10.1111/j.1365-2621.1985.tb13295.x. 
[33] P. Fäldt, B. Bergenståhl, Spray-dried whey protein/lactose/soybean oil emulsions. 2. Redispersability, wettability and particle structure, Food Hydrocoll. 10 (1996) 431-439. doi:10.1016/S0268-005X(96)80021-X.

[34] S. Khem, D.M. Small, B.K. May, The behaviour of whey protein isolate in protecting Lactobacillus plantarum, Food Chem. 190 (2016) 717-723. doi:10.1016/j.foodchem.2015.06.020.

[35] Q. Shen, S.Y. Quek, Microencapsulation of astaxanthin with blends of milk protein and fiber by spray drying, J. Food Eng. 123 (2014) 165-171. doi:10.1016/j.jfoodeng.2013.09.002.

[36] M.J. Maltesen, S. Bjerregaard, L. Hovgaard, S. Havelund, M. van de Weert, Quality by design Spray drying of insulin intended for inhalation, Eur. J. Pharm. Biopharm. 70 (2008) 828-838. doi:10.1016/j.ejpb.2008.07.015.

[37] C. Anandharamakrishnan, C.D. Rielly, A.G.F. Stapley, Effects of Process Variables on the Denaturation of Whey Proteins during Spray Drying, Dry. Technol. 25 (2007) 799-807. doi:10.1080/07373930701370175.

[38] M. Donovan, D.M. Mulvihill, Thermal Denaturation and Aggregation of Whey Proteins, Ir. J. Food Sci. Technol. 11 (1987) 87-100.

[39] Ó.L. Ramos, I. Reinas, S.I. Silva, J.C. Fernandes, M.A. Cerqueira, R.N. Pereira, A.A. Vicente, M.F. Poças, M.E. Pintado, F.X. Malcata, Effect of whey protein purity and glycerol content upon physical properties of edible films manufactured therefrom, Food Hydrocoll. 30 (2013) 110122. doi:10.1016/j.foodhyd.2012.05.001.

[40] D.M. Byler, H. Susi, Examination of the secondary structure of proteins by deconvolved FTIR spectra, Biopolymers. 25 (1986) 469-487. doi:10.1002/bip.360250307.

[41] A.-F. Allain, P. Paquin, M. Subirade, Relationships between conformation of $\beta$-lactoglobulin in solution and gel states as revealed by attenuated total reflection Fourier transform infrared spectroscopy, Int. J. Biol. Macromol. 26 (1999) 337-344. doi:10.1016/S0141-8130(99)00104-X.

[42] Y. Fang, D.G. Dalgleish, Conformation of $\beta$-Lactoglobulin Studied by FTIR: Effect of pH, Temperature, and Adsorption to the Oil-Water Interface, J. Colloid Interface Sci. 196 (1997) 292-298. doi:10.1006/jcis.1997.5191.

[43] T. Lefèvre, M. Subirade, M. Pézolet, Molecular description of the formation and structure of plasticized globular protein films, Biomacromolecules. 6 (2005) 3209-3219. doi:10.1021/bm050540u.

[44] V. Gilbert, M. Rouabhia, H. Wang, A.-L. Arnould, G. Remondetto, M. Subirade, Characterization and evaluation of whey protein-based biofilms as substrates for in vitro cell cultures, Biomaterials. 26 (2005) 7471-7480. doi:10.1016/j.biomaterials.2005.05.085.

[45] K.G. Carrasquillo, A.M. Stanley, J.C. Aponte-Carro, P. De Jésus, H.R. Costantino, C.J. Bosques, K. Griebenow, Non-aqueous encapsulation of excipient-stabilized spray-freeze dried BSA into poly(lactide-co-glycolide) microspheres results in release of native protein, J. Controlled Release. 76 (2001) 199-208. doi:10.1016/S0168-3659(01)00430-8.

[46] M. Ijaz, A. Bernkop-Schnürch, Preactivated thiomers: their role in drug delivery, Expert Opin. Drug Deliv. 12 (2015) 1269-1281. doi:10.1517/17425247.2015.1005598.

[47] S. Bonengel, A. Bernkop-Schnürch, Thiomers - From bench to market, J. Control. Release Off. J. Control. Release Soc. (2014). doi:10.1016/j.jconrel.2014.06.047.

[48] C. Gaiani, M. Morand, C. Sanchez, E.A. Tehrany, M. Jacquot, P. Schuck, R. Jeantet, J. Scher, How surface composition of high milk proteins powders is influenced by spray-drying temperature, Colloids Surf. B Biointerfaces. 75 (2010) 377-384. doi:10.1016/j.colsurfb.2009.09.016.

[49] D.H.G. Pelegrine, C.A. Gasparetto, Whey proteins solubility as function of temperature and pH, LWT - Food Sci. Technol. 38 (2005) 77-80. doi:10.1016/j.lwt.2004.03.013.

[50] C. Anandharamakrishnan, C.D. Rielly, A.G.F. Stapley, Loss of solubility of $\alpha$-lactalbumin and $\beta$ lactoglobulin during the spray drying of whey proteins, LWT - Food Sci. Technol. 41 (2008) 270277. doi:10.1016/j.Iwt.2007.03.004. 
[51] T.H. McHUGH, J.-F. Aujard, J.M. Krochta, Plasticized Whey Protein Edible Films: Water Vapor Permeability Properties, J. Food Sci. 59 (1994) 416-419. doi:10.1111/j.13652621.1994.tb06980.x.

[52] Y.H. Yun, B.K. Lee, K. Park, Controlled Drug Delivery: Historical perspective for the next generation, J. Control. Release Off. J. Control. Release Soc. 219 (2015) 2-7. doi:10.1016/j.jconrel.2015.10.005.

[53] A.L. Smart, S. Gaisford, A.W. Basit, Oral peptide and protein delivery: intestinal obstacles and commercial prospects, Expert Opin. Drug Deliv. 11 (2014) 1323-1335. doi:10.1517/17425247.2014.917077.

[54] C. Gaiani, P. Schuck, J. Scher, S. Desobry, S. Banon, Dairy powder rehydration: influence of protein state, incorporation mode, and agglomeration, J. Dairy Sci. 90 (2007) 570-581. doi:10.3168/jds.S0022-0302(07)71540-0.

[55] E.H.-J. Kim, X.D. Chen, D. Pearce, Surface characterization of four industrial spray-dried dairy powders in relation to chemical composition, structure and wetting property, Colloids Surf. B Biointerfaces. 26 (2002) 197-212. doi:10.1016/S0927-7765(01)00334-4.

[56] Z. Gao, In Vitro Dissolution Testing with Flow-Through Method: A Technical Note, AAPS PharmSciTech. 10 (2009) 1401-1405. doi:10.1208/s12249-009-9339-6.

[57] C.A. Withers, M.T. Cook, L. Methven, M.A. Gosney, V.V. Khutoryanskiy, Investigation of milk proteins binding to the oral mucosa, Food Funct. 4 (2013) 1668-1674. doi:10.1039/C3FO60291E.

[58] G.P. Andrews, T.P. Laverty, D.S. Jones, Mucoadhesive polymeric platforms for controlled drug delivery, Eur. J. Pharm. Biopharm. 71 (2009) 505-518. doi:10.1016/j.ejpb.2008.09.028.

[59] A. Bernkop-Schnürch, The use of inhibitory agents to overcome the enzymatic barrier to perorally administered therapeutic peptides and proteins, J. Controlled Release. 52 (1998) 116. doi:10.1016/S0168-3659(97)00204-6.

[60] Y. Birk, The Bowman-Birk inhibitor. Trypsin- and chymotrypsin-inhibitor from soybeans, Int. J. Pept. Protein Res. 25 (1985) 113-131.

[61] W. Strober, Trypan Blue Exclusion Test of Cell Viability, Curr. Protoc. Immunol. Ed. John E Coligan Al. 111 (2015) A3.B.1-3. doi:10.1002/0471142735.ima03bs111.

[62] E. Touitou, B.W. Barry, Enhancement in Drug Delivery, CRC Press, 2006.

[63] Y. Sambuy, I. De Angelis, G. Ranaldi, M.L. Scarino, A. Stammati, F. Zucco, The Caco-2 cell line as a model of the intestinal barrier: influence of cell and culture-related factors on Caco- 2 cell functional characteristics, Cell Biol. Toxicol. 21 (2005) 1-26. doi:10.1007/s10565-005-0085-6. 
a)

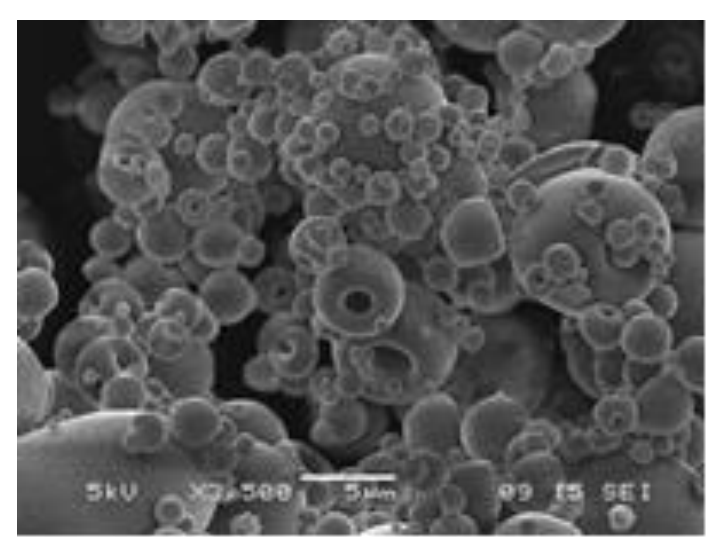

b)

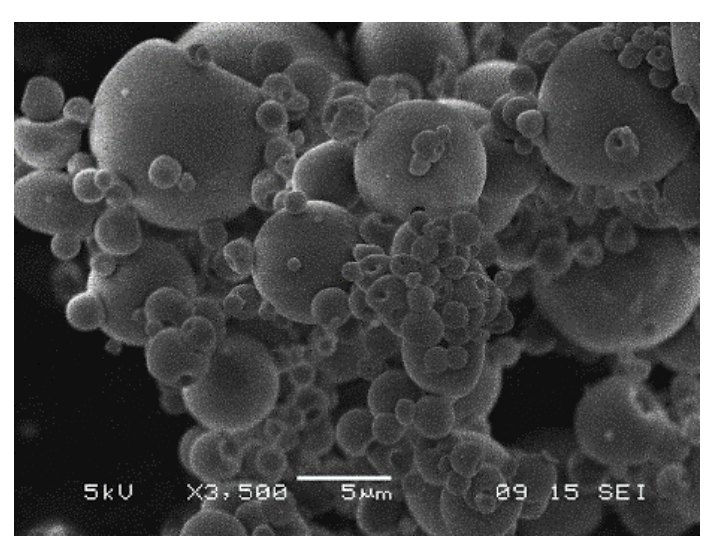

Fig. 1. SEM images (x3500) for spray-dried WP particle samples: (a) NWP, (b) DWP (10\% WP content, inlet temperature $160^{\circ} \mathrm{C}$, pump rate $5.7 \mathrm{mg} \cdot \mathrm{min}^{-1}$ and $\mathrm{Q}$-flow $50 \mathrm{mmHg}$ ). 
a)

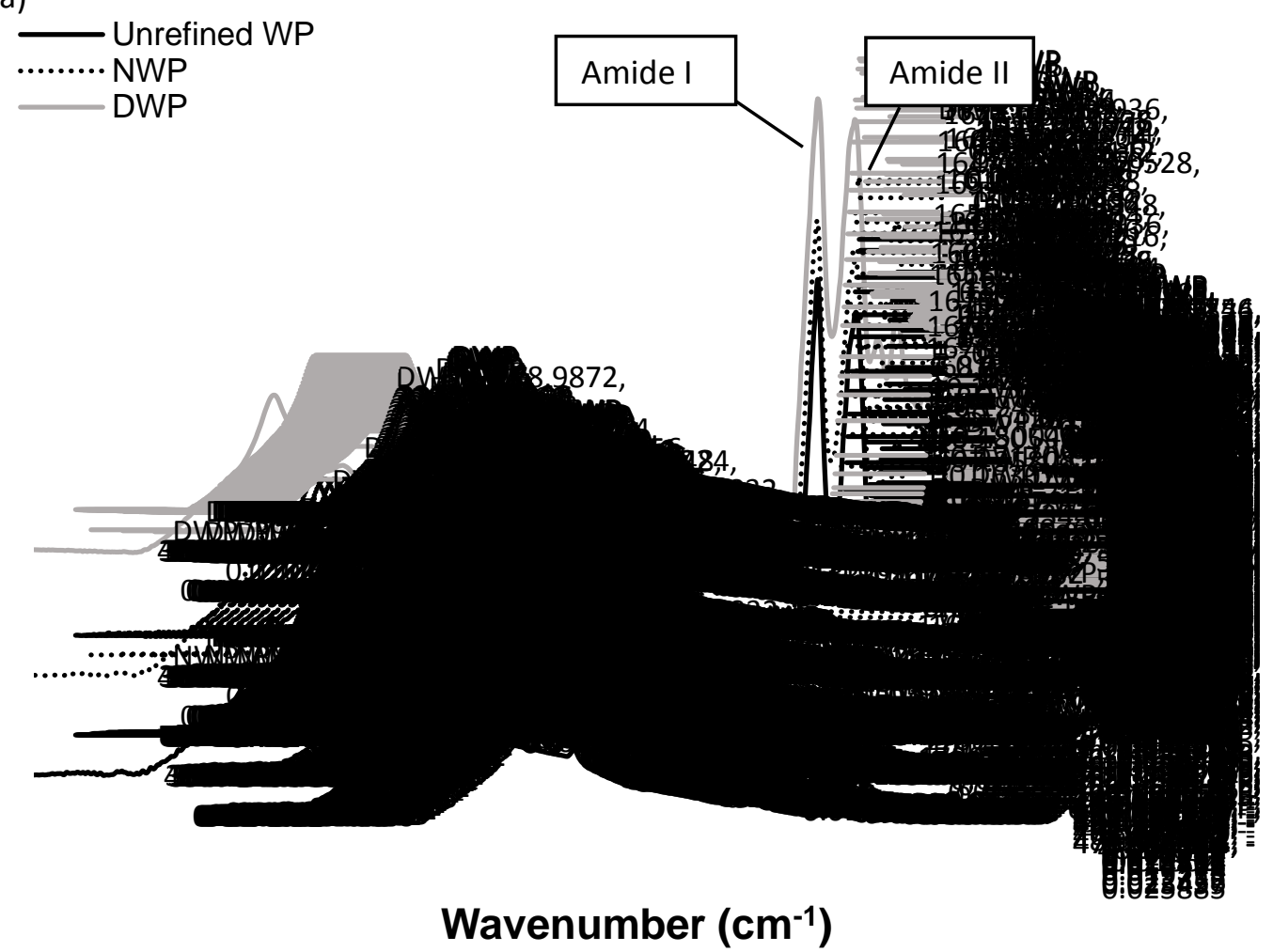

b)

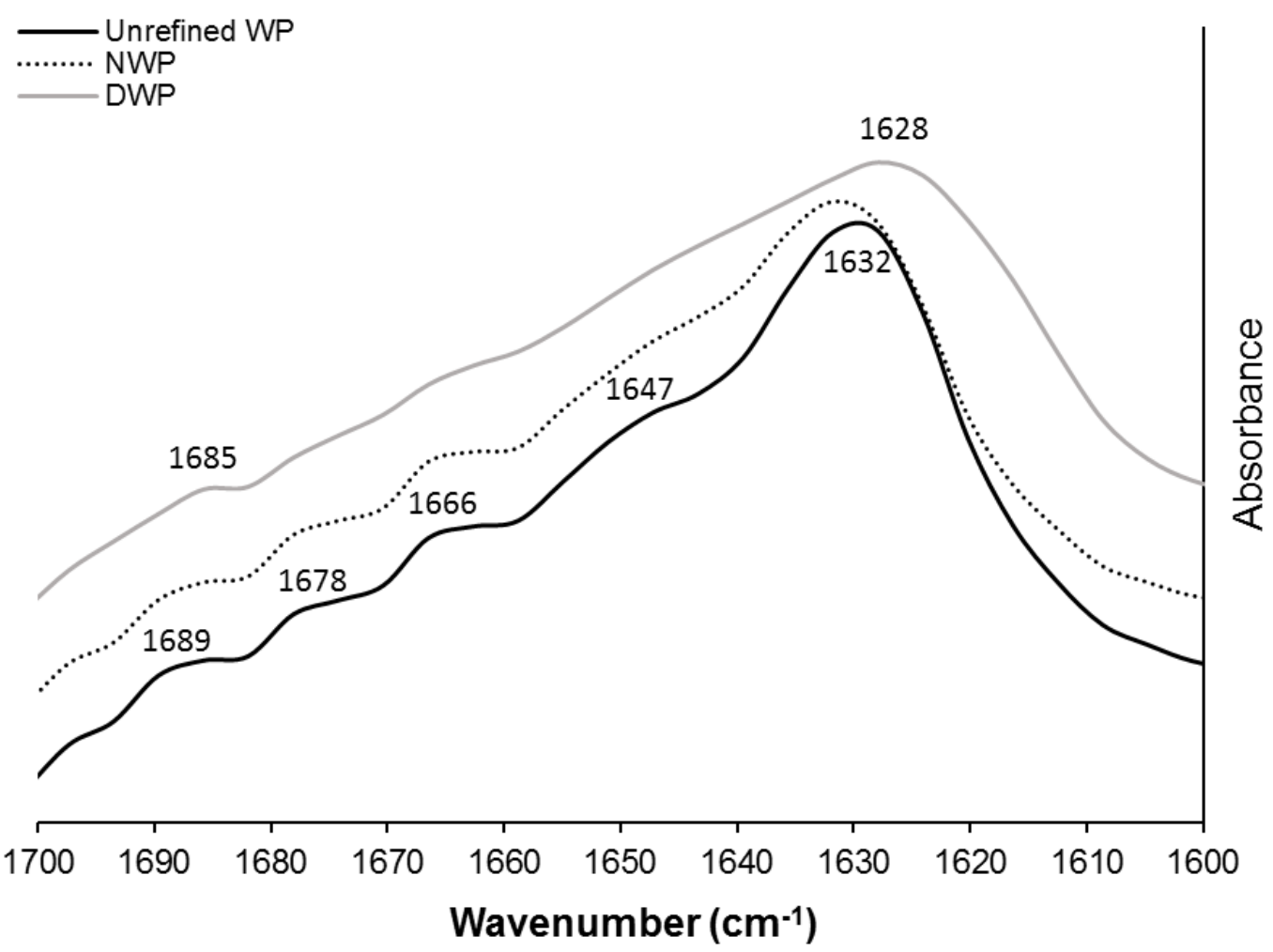

Fig. 2. (a) FTIR spectra of unrefined WP and spray-dried NWP or DWP powders and (b) deconvoluted spectra of these powders in the amide I region $\left(1600-1700 \mathrm{~cm}^{-1}\right)$. 


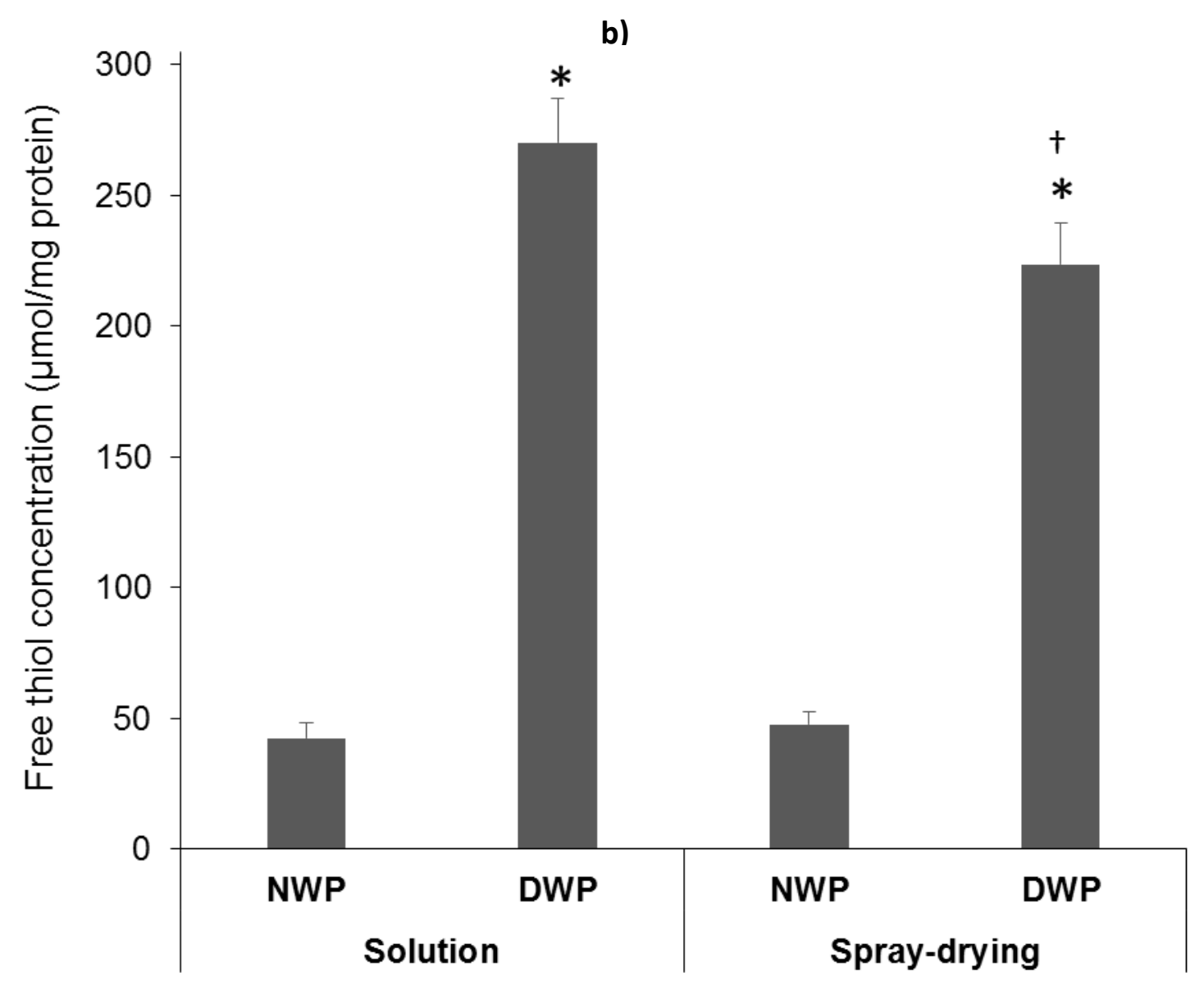

Fig. 3. Comparison of free thiol concentrations in liquid and in spray-dried samples: influence of denaturation and glycerol addition $(n=3$, mean $\pm S D, *$ and $+p<0.05$ significantly different from solution of NWP and DWP respectively). 
b)

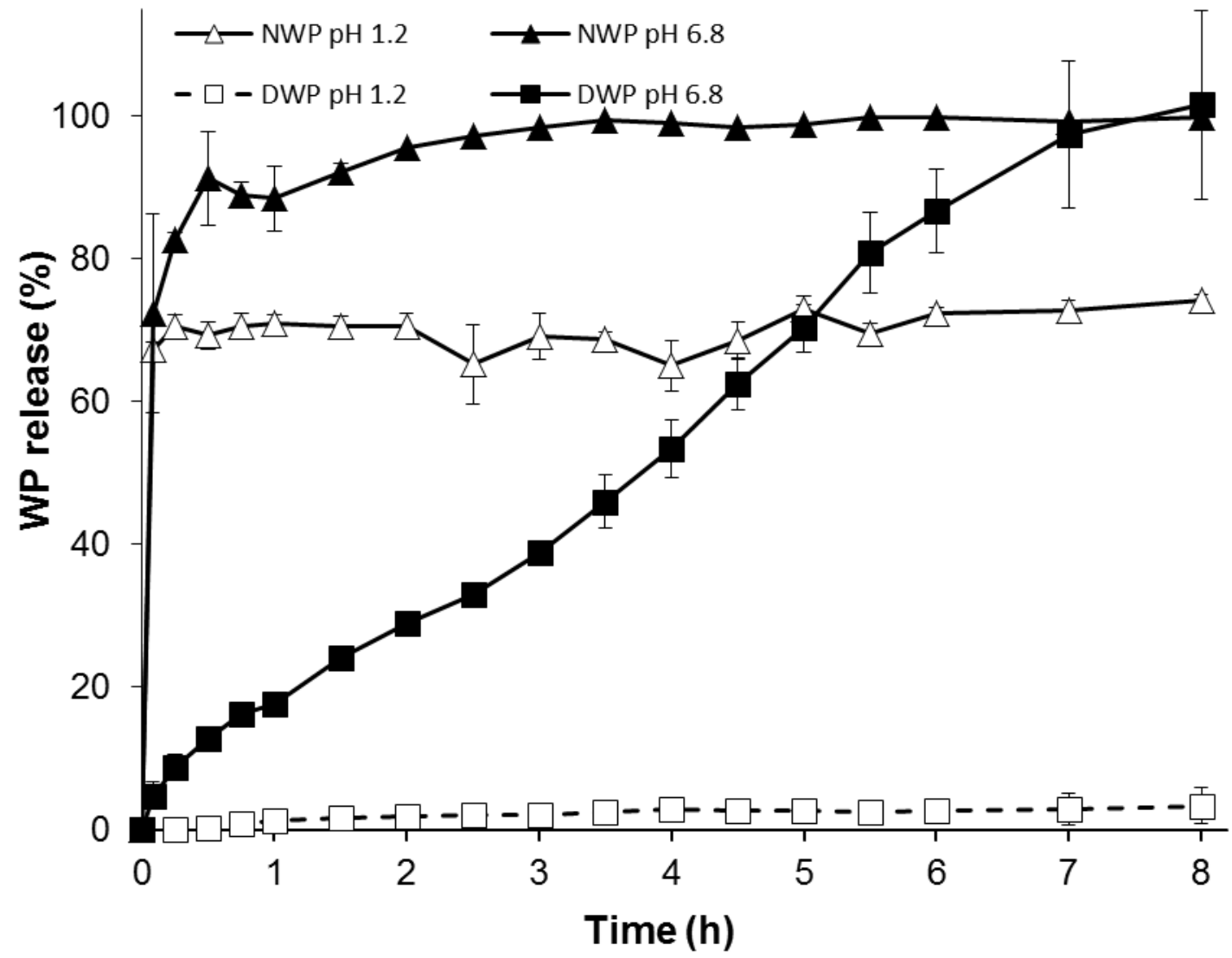

Fig. 4. WP release from $(\Delta)$ NWP and $(\square)$ DWP powders obtained by spray-drying, at $p H 1.2$ (open symbol) or pH 6.8 (closed symbol) during $8 \mathrm{~h}$ in USP 4 closed system ( $n=3$, mean \pm SD). 


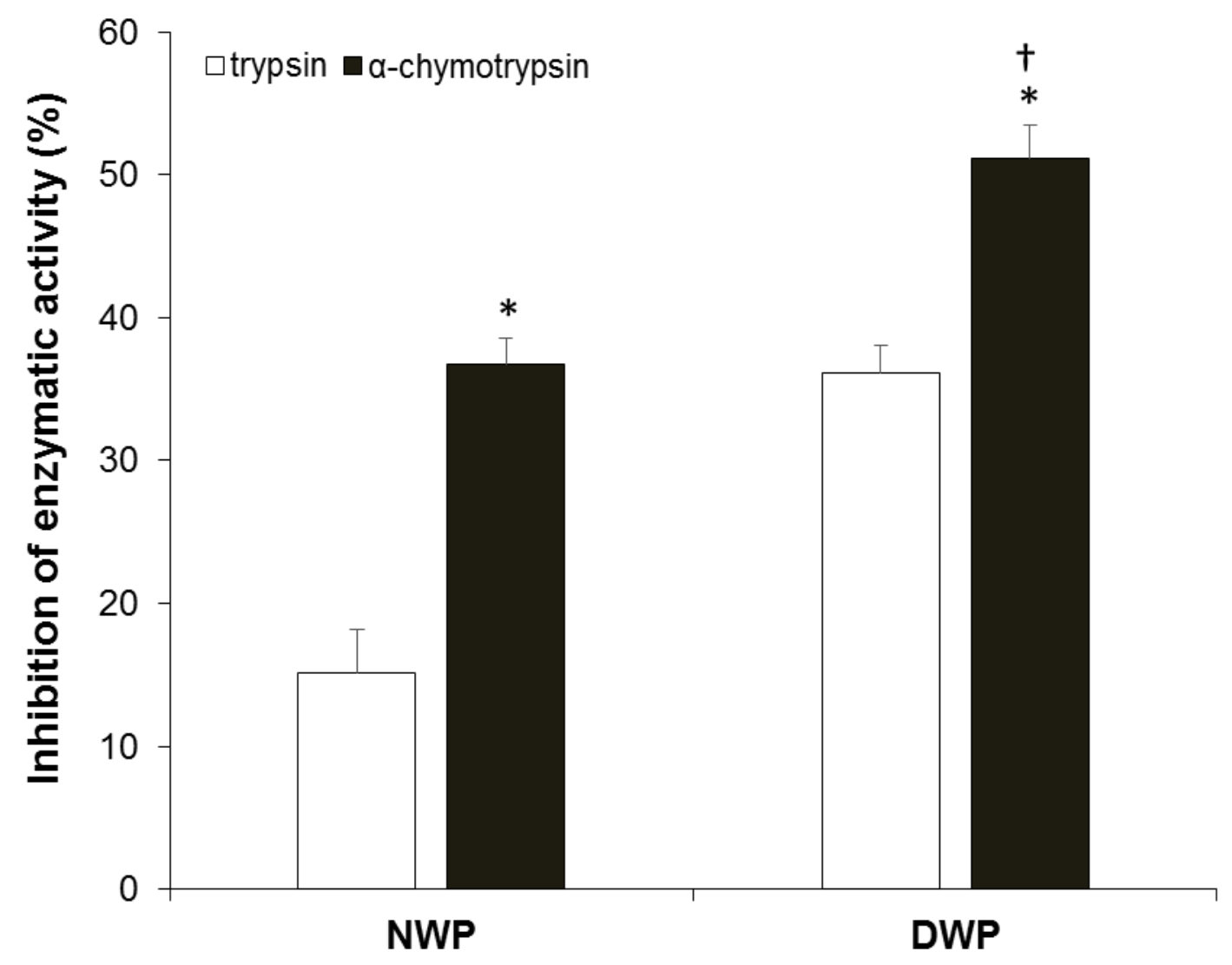

Fig. 5. In vitro trypsin and chymotrypsin inhibitory effect of NWP and DWP powders obtained by spray-drying $(n=3$, mean $\pm S D, *$ and $+p<0.05$ significantly different from trypsin and NWP respectively). 


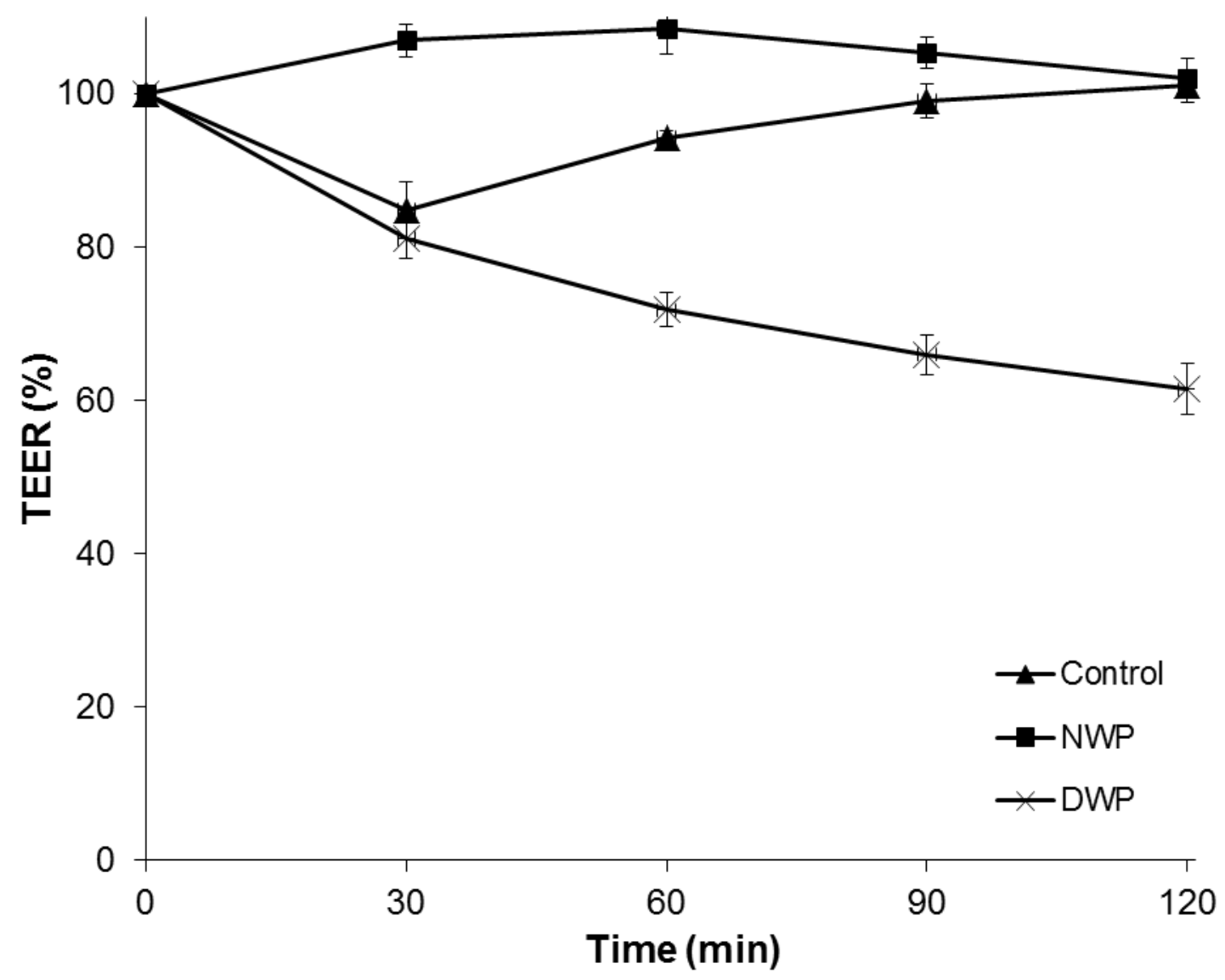

Fig. 6. TEER (\%) values obtained on Caco- 2 cells after $2 \mathrm{~h}$ incubation of NWP, DWP and DWPGly powders on Caco- 2 cells $(n=3$, mean $\pm S D$ ). 


\section{Table 1.}

Spray-drying of WP solutions (10\%, w/w): Evaluation of response variables (yield, residual humidity, outlet temperature and particle size) as a function of applied process parameters (inlet temperature $160^{\circ} \mathrm{C}$, pump rate $5.7 \mathrm{mg} \cdot \mathrm{min}^{-1}$ and $\mathrm{Q}$-flow $\left.50 \mathrm{mmHg}\right)(\mathrm{n}=3 \pm \mathrm{SD}$ ).

\begin{tabular}{l|l|l|}
\hline WP form & NWP & DWP \\
\hline Yield (\%) & $87.3 \pm 0.1$ & $80.8 \pm 0.4$ \\
Residual humidity (\%) & $4.5 \pm 0.2$ & $3.9 \pm 1.2$ \\
Outlet temperature ( $\left.{ }^{\circ} \mathrm{C}\right)$ & $88.6 \pm 1.2$ & $72 \pm 1.0$ \\
D [3,2] $\mu \mathrm{m}$ & $4.2 \pm 2.6$ & $4.2 \pm 2.7$ \\
\hline
\end{tabular}


Table 2.

Solubility (mg. $\mathrm{mL}^{-1}$ ) of WP powders (unrefined WP, NWP-sp or DWP-sp) in pH 1.2, 4.5, 6.8 or 7.5 buffers $(n=3$, mean $\pm S D)$.

\begin{tabular}{lllll} 
Buffer & pH 1.2 & pH 4.5 & pH 6.8 & pH 7.5 \\
\hline Unrefined WP & $502.6 \pm 30.8$ & $772.5 \pm 51.2$ & $835.2 \pm 47.2$ & $872.5 \pm 39.7$ \\
NWP & $469.8 \pm 26.9$ & $723.4 \pm 38.5$ & $784.4 \pm 33.8$ & $867.6 \pm 33.3$ \\
DWP & $2.2( \pm 0.3) .10^{-3}$ & $8.8 \pm 0.3$ & $14.4 \pm 2.1$ & $16.9 \pm 1.4$ \\
\hline
\end{tabular}


Table 3.

Mean apparent permeability $\left(\mathrm{P}_{\mathrm{app}}\right)$ of PEG 4000 and absorption enhancement ratio $(\mathrm{R})$ across Caco-2 cell monolayers, alone (control, free PEG) or with NWP-sp or DWP-sp powder after $2 \mathrm{~h}$ incubation ( $\mathrm{n}=3$, mean $\pm S D, * p<0.05$ significantly different from control).

\begin{tabular}{lllll}
\hline Sample & Absorption & & Papp & $\mathrm{R}$ \\
& & & \\
& $\mu \mathrm{g}$ & $\%$ & $\times\left(10^{-6} . \mathrm{cms}^{-1}\right)$ & \\
\hline Control & $52.96 \pm 2.55$ & $11.21 \pm 0.54$ & $6.95 \pm 0.03$ & 1.00 \\
NWP & $47.72 \pm 2.40$ & $10.36 \pm 0.52$ & $6.42 \pm 0.03$ & 0.92 \\
DWP & $100.44 \pm 5.02$ & $21.80 \pm 1.09$ & $13.20 \pm 0.06^{*}$ & $1.91^{*}$ \\
\hline
\end{tabular}

